\title{
Comparison of the levels of antenatal anxiety in pregnant women admitted for delivery before and after COVID-19 outbreak in Turkey
}

\author{
Oğuz Güler ${ }^{1}$ (D), Şafak Hatırnaz ${ }^{2}$ \\ ${ }^{1}$ Bilge Hospital, İstanbul, Turkey \\ ${ }^{2}$ IVF Center, Medicana Samsun International Hospital, Samsun, Turkey
}

\begin{abstract}
Objective: This study aimed to compare the level of anxiety in pregnant women who were admitted to our institute before and after confirmation of COVID-19 outbreak have reached Turkey.

Methods: One-hundred and fifty consecutive pregnant women admitted to our institute following the emergence of the global COVID-19 outbreak (Group 1) and 150 age-matched pregnant women who were admitted to our institute for delivery following the confirmation of COVID-19 outbreak have reached Turkey (Group 2 ) were enrolled in this study. All patients were asked to fill out the State and Trait Anxiety Inventory (STAI).

Results: STAI-Trait scores, which reflect long term anxiety levels were similar in subjects admitted to our institute for delivery before the COVID-19 outbreak in Turkey compared to those admitted after COVID-19 outbreak $(42.5 \pm 5.8$ vs. $42.2 \pm 3.2$, respectively; $\mathrm{p}=0.487)$. However, there was a significant difference in STAI-State scores, indicating state anxiety, between subjects admitted to our institute for delivery before and after confirmation of COVID-19 outbreak in Turkey (44.6 \pm 5.3 vs. $42.9 \pm 5.1$, respectively; $\mathrm{p}=0.05$ ).

Conclusion: Pregnant women admitted to our institute for delivery subsequent to the announcement of first COVID-19 case and declaration of the state of alarm have higher levels of state anxiety compared to those admitted before the establishment of first COVID-19 cases and containment measures.
\end{abstract}

Keywords: COVID-19, antenatal anxiety, pregnant.

\section{Introduction}

Several cases of pneumonia with unknown etiology have emerged in Wuhan, Hubei Province, China towards the end of the 2019. ${ }^{[1]}$ Fewer and cough, which were prior to
Özet: Türkiye'de COVID-19 salgınından önce ve sonra doğum için başvuran gebelerde antenatal kaygı seviyelerinin karşılaştııılması

Amaç: Bu çalışmada, COVID-19 salgınının Türkiye'ye ulaştığının doğrulanmasından önce ve sonra kurumumuza başvuran gebelerin kaygı seviyelerini karşılaştırmayı amaçladık.

Yöntem: Küresel COVID-19 salgınının ortaya çıkmasının ardından kurumumuza başvuran 150 ardışı gebe (Grup 1) ve COVID19 salgınının Türkiye'ye ulaştığının doğrulanmasının ardından doğum için kurumumuza başvuran yaş uyumlu 150 gebe (Grup 2) çalışmaya dahil edildi. Tüm hastalardan Durumluk-Sürekli Kaygı Envanterini (DSKE) doldurmaları istendi.

Bulgular: Uzun süreli kaygı seviyelerini gösteren DSKE-Sürekli puanları, COVID-19 salgını sonrası başvuranlara kıyasla Türkiye'de COVID-19 salgınının ortaya çıkmasından önce doğum için kurumumuza başvuran olgularda benzerdi (sırasıyla $42.2 \pm 3.2$ ve 42.5 $\pm 5.8 ; \mathrm{p}=0.487$ ). Ancak durumluk kaygıyı gösteren DSKE-Durumluk puanlarında, Türkiye'de COVID-19 salgınının doğrulanmasından önce ve sonra doğum için kurumumuza başvuran olgular arasında anlamlı bir fark vardı (sırasıyla $44.6 \pm 5.3$ ve $42.9 \pm 5.1$; $\mathrm{p}=0.05$ ).

Sonuç: İlk COVID-19 vakasının duyurulmasından ve acil durum ilanından sonra doğum için kurumumuza başvuran gebeler, ilk COVID-19 vakalarının ortaya çıkmasından ve karantina tedbirlerinin uygulanmasından önce başvuranlara kıyasla daha yüksek durumluk kaygi seviyelerine sahiptir.

Anahtar sözcükler: COVID-19, antenatal kaygı, gebe.

an acute respiratory distress syndrome were the most prominent initial symptoms. ${ }^{[2]}$ Following the identification of a novel coronavirus in the throat swab sample of one patient by the Chinese Center for Disease Control

Correspondence: Oğuz Güler, MD. Bilge Hastanesi, Şemsipaşa Mahallesi, 56. Sokak, No: 2, Gaziosmanpaşa, İstanbul, Turkey.

e-mail: oguz_gulers@yahoo.com / Received: June 1, 2020; Accepted: June 17, 2020

Please cite this article as: Güler O, Hatırnaz Ş. Comparison of the levels of antenatal anxiety in pregnant women admitted for delivery before and after COVID-19 outbreak in Turkey. Perinatal Journal 2020;28(2):108-112. doi:10.2399/prn.20.0282014 
and Prevention (CDC), World Health Organization (WHO) named the novel coronavirus as $2019 \mathrm{nCoV} .^{[3]}$ The rapid spread of the pneumonia to other regions of China and overseas led World Health Organization (WHO) declare this outbreak as the public health emergency of international concern (PHEIC). In February 2020, the virus was renamed as severe acute respiratory syndrome coronavirus-2 (SARS-CoV-2) by the International Committee on Taxonomy of Viruses. ${ }^{[4]}$ Epidemic disease caused by SARS-CoV-2 was further announced by the WHO as coronavirus disease 2019 (COVID-19).

Coronavirus disease 2019 was the third coronavirus disease within the last two decades following severe acute respiratory syndrome coronavirus (SARS-CoV) which resulted in more than 8000 infections and 774 deaths in 37 countries, and Middle East respiratory syndrome coronavirus (MERS-CoV) which resulted in 2494 infections 858 deaths. $^{[5,6]}$ As of May 25, 2020, COVID-19 has been reported to affect about 5.5 million individuals and caused over 340.000 fatalities globally ${ }^{[5]}$ The high virulence, rapid spread and related mortality alerted healthcare authorities and many of the countries announced containment measures to slowdown the spread of the COVID-19. Accumulating data indicate that declaration of the state of alarm by many countries and related containment measures along with the public-health messages not only raised public's knowledge concerning the COVID-19 but also led to global anxiety resulting from the fear of being infected by the SARS-CoV-2. ${ }^{[7-10]} \mathrm{A}$ number of studies have shown that antenatal anxiety could result in adverse perinatal outcomes. ${ }^{[1]]}$ Given that COVID-19 may trigger excessive anxiety, we hypothesized that the announcement of containment measures as a consequence of the arrival of COVID-19 in our country would trigger anxiety in pregnant women.

This study aimed to compare the level of anxiety in pregnant women who were admitted to our institute before and after confirmation of COVID-19 outbreak have reached Turkey.

\section{Methods}

One-hundred and fifty consecutive pregnant women aged between 18 and 35 years who were admitted to the our hospital following the emergence of the global
COVID-19 outbreak (Group 1) and 150 age-matched pregnant women who were admitted to our institute for delivery following the confirmation of COVID-19 outbreak have reached Turkey (Group 2, before March 11, 2020) were enrolled in this study. Women with previous anxiety disorders or mental syndromes, high blood pressure, lung, kidney, or heart problems, diabetes, autoimmune disease, sexually transmitted diseases, preeclampsia, multiple pregnancies, placenta previa were excluded. Written informed consent was obtained from all subjects included in the study. The study was approved by the Institutional Ethical Committee and was performed in accordance with the recent version of the Helsinki Declaration. The power calculation was based on our pilot study with the first 15 patients. We used "priori ttests; the difference between two independent means" for post-information State and Trait Anxiety InventoryState (STAI-S) measurements in the two groups (Group 2 patients: $45.3 \pm 4.6$, STAI-S score of Group 1 patients: $42.4 \pm 4.2$, alpha error: 0.05 , power: 0.95 , effect size: $0.65) .{ }^{[12]}$ Results showed that at least 102 patients were required for an adequate sample size.

All patients were asked to fill out the STAI, which is a validated and widely used self-report questionnaire assessing both state and trait anxiety. ${ }^{[13,14]}$ STAI includes two questionnaires with 20 questions in each; STAI-S, which intends to evaluate the current state of anxiety, and trait anxiety (STAI-T) that measures long term anxiety levels. Responses for the STAI-S scale evaluate the intensity of current feelings "right now": (1) not at all, (2) somewhat, (3) moderately so, and (4) very much so. Responses for the STAI-T scale evaluate the frequency of feelings "in general": (1) almost never, (2) sometimes, (3) often, and (4) almost always. Item scores are added to obtain subtest total scores. Each answer was scored on a scale of 1-4 and was added to reach a final score. The overall score ranges between 20 and 80, the higher score indicating greater anxiety.

The difference between the anxiety levels of subjects in Group1 and Group 2 was the primary outcome measure of this study. Statistical analyses were carried out using SPSS for Windows, version 17 (SPSS, Chicago, IL, USA). Continuous variables were presented as mean \pm standard deviation $($ mean $\pm \mathrm{SD})$ and categorical variables as frequency (n) and percentage (\%). KolmogorovSmirnov test was used to determine the normal distribution of the data. The comparison of the two groups was 
Table 1. Comparison of demographic characteristics and anxiety scores between the study groups

\begin{tabular}{lccc} 
& Group 1 & Group 2 & \\
$\mathbf{n = 1 5 0}$ & $\mathbf{n}=\mathbf{1 5 0}$ & $\mathbf{p}$-value \\
\hline Age, years & $29.1 \pm 5.1$ & $28.2 \pm 4.3$ & 0.141 \\
\hline Week of gestation, $\mathrm{n}$ & $39.6 \pm 2.1$ & $39.3 \pm 1.4$ & 0.211 \\
\hline Body mass index, $\mathrm{kg} / \mathrm{m}^{2}$ & $28.2 \pm 3.3$ & $28.5 \pm 2.8$ & 0.198 \\
\hline Gravidity, $\mathrm{n}$ & $1.84 \pm 0.43$ & $1.85 \pm 0.58$ & 0.903 \\
\hline Parity, $\mathrm{n}$ & $0.69 \pm 0.07$ & $0.78 \pm 0.07$ & 0.239 \\
\hline STAl-State & $44.6 \pm 5.3$ & $42.9 \pm 5.1$ & 0.005 \\
\hline STAl-Trait & $42.5 \pm 5.8$ & $42.2 \pm 3.2$ & 0.487 \\
\hline
\end{tabular}

Data are presented as mean \pm standard deviation. STAI: State and Trait Anxiety Inventory.

performed with Student's t-test, Mann-Whitney U test, $\chi^{2}$-test or Fisher's exact test, where appropriate. Twosided p-value $\leq 0.05$ was interpreted as statistically significant.

\section{Results}

The mean age and the mean week of gestation of the study subjects were $28.6 \pm 4.7$ years and $35.5 \pm 2.1$ weeks, respectively. The two groups were similar with respect to age, week of gestation, body mass index, gravidity, and parity. STAI-T scores, which reflect long term anxiety levels were similar in subjects admitted to our institute for delivery before the confirmation of COVID-19 outbreak have reached our country compared to those admitted after COVID-19 outbreak have reached our country ( $42.5 \pm 5.8$ vs. $42.2 \pm 3.2$, respectively; $\mathrm{p}=0.487)$. However, there was a significant difference in STAIState scores, indicating state anxiety, between the subjects admitted to our institute for delivery before and after confirmation of COVID-19 outbreak have reached our country ( $44.6 \pm 5.3$ vs. $42.9 \pm 5.1$, respectively; $\mathrm{p}=0.05$ ) (Table 1).

\section{Discussion}

Despite similar long-term anxiety scores between the two groups, our findings show that subjects admitted to our institute for delivery following the confirmation of COVID-19 outbreak have reached our country had higher levels of state anxiety compared to subjects admitted before the confirmation of COVID-19 outbreak have reached our country.

Antenatal anxiety, which is shown to affect about $20 \%$ of pregnant women, has been reported to be asso- ciated with adverse outcomes for both mother and baby following delivery. ${ }^{[15]}$ While postpartum hemorrhage, and postpartum depression are more frequent in pregnant with antenatal anxiety, preterm birth, low mean birth weight, and small head circumference might be observed in infants born to mothers with antenatal anxiety. ${ }^{[1-20]}$ Moreover, measures aiming to relieve anxiety have been shown to improve pregnancy outcomes in women with antenatal anxiety. ${ }^{[21,22]}$

Turkish Ministry of Health announced the first COVID-19 case in Turkey on March 11, 2020. A state of alarm, including several containment measures such as school closures, transport bans and workplace shutdowns has been established following this first case. Individuals $<20$ years and $>65$ years were obliged to stay at home since this population may either be vulnerable to complications of COVID-19 or may facilitate the spreading of the COVID-19. Elective interventional and surgical procedures were also postponed due to the heavy burden on the healthcare systems loaded by COVID-19 cases. Television programs started to broadcast certain public messages regarding the virulence and rapid spread of SARS-CoV-2 and global mortality from COVID-19. Following the establishment of containment measures by governments, many of the individuals are observed to hesitate seeking medical help even for emergency situations. ${ }^{[23]}$ There are several recent reports demonstrating a dramatic decline in hospital admissions even from life-threatening conditions such as acute myocardial infarction or acute heart failure after containment measures. ${ }^{[24-26]}$ It simply appears that declaration of the state of alarm by many countries and related containment measures along with the public-health messages have created a global anxiety among individuals requiring healthcare for causes other than COVID-19 and led 
to a self-censorship resulting from the possible contamination in hospitals. A recent study from China has shown that initial phase of the COVID-19 outbreak triggered extensive anxiety among general population. ${ }^{[7]}$ Another study among active Weibo users has reported short-term individual changes in psychological conditions after the outbreak. ${ }^{[27]}$

Currently, there are only a few studies investigated the role of COVID-19 outbreak on antenatal anxiety. The study of Durankus et al., which included an online questionnaire consisting of depression and anxiety inventories, has shown that COVID-19 pandemic had critical impact on the depression and anxiety levels of pregnant women. ${ }^{[28]}$ A multi-center cross-sectional study from China, which compared the mental status of pregnant women before and after the announcement of the COVID-19 epidemic has reported that pregnant women assessed after the declaration of COVID-19 epidemic had significantly higher levels of anxiety and higher rates of depressive symptoms compared to women assessed prior to announcement of the COVID-19 epidemic. ${ }^{[29]}$ However, there is still gap in data regarding the role of COVID-19 outbreak on antenatal anxiety.

This study shows that pregnant women admitted after announcement of the first COVID-19 case and containment measures in Turkey had higher levels of anxiety compared to women admitted before containment measures. Our findings confirm the results of the previous two studies indicating higher levels of anxiety in pregnant women following the COVID-19 outbreak. The lack of a significant difference in STAI-T scores between subjects admitted before and after COVID-19 outbreak indicates that psychological impact of the outbreak is short-term and is associated with either the COVID-19 outbreak itself or with the containment measures established to prevent the spread of the disease. Strategies targeting to relieve maternal stress should be provided by all decision-makers, health authorities, and health care professionals to prevent potential adverse pregnancy outcomes which are closely linked with antenatal anxiety.

\section{Conclusion}

Results of this study clearly shows that pregnant women admitted to our institute for delivery subsequent to the announcement of first COVID-19 case and declaration of the state of alarm have higher levels of state anxiety compared to those admitted before the establishment of first COVID-19 cases and containment measures. Given the negative impact of antenatal anxiety on pregnancy outcomes, we consider that health authorities should provide strategies targeting to relieve maternal stress on pregnant women.

Conflicts of Interest: No conflicts declared.

\section{References}

1. Wang D, Hu B, Hu C, Zhu F, Liu X, Zhang J, et al. Clinical characteristics of 138 hospitalized patients with 2019 novel Coronavirus-infected pneumonia in Wuhan, China. JAMA 2020;323:1061-9. [PubMed] [CrossRef]

2. Harapan H, Itoh N, Yufika A, Winardi W, Keam S, Te H, et al. Coronavirus disease 2019 (COVID-19): a literature review. J Infect Public Health 2020;13:667-73. [PubMed] [CrossRef]

3. Huang C, Wang Y, Li X, Ren L, Zhao J, Hu Y, et al. Clinical features of patients infected with 2019 novel Coronavirus in Wuhan, China. Lancet 2020;395:497-506. [PubMed] [CrossRef]

4. Ge H, Wang X, Yuan X, Xiao G, Wang C, Deng T, et al. The epidemiology and clinical information about COVID-19. Eur J Clin Microbiol Infect Dis 2020;39:1011-9. [PubMed] [CrossRef]

5. Lu R, Zhao X, Li J, Niu P, Yang B, Wu H, et al. Genomic characterisation and epidemiology of 2019 novel Coronavirus: implications for virus origins and receptor binding. Lancet 2020;395:565-74. [PubMed] [CrossRef]

6. de Wit E, van Doremalen N, Falzarano D, Munster VJ. SARS and MERS: recent insights into emerging coronaviruses. Nat Rev Microbiol 2016;14:523-34. [PubMed] [CrossRef]

7. Wang C, Pan R, Wan X, Tan Y, Xu L, Ho CS, et al. Immediate psychological responses and associated factors during the initial stage of the 2019 Coronavirus disease (COVID-19) epidemic among the general population in China. Int J Environ Res Public Health 2020;17:1729. [PubMed] [CrossRef]

8. Cao W, Fang Z, Hou G, Han M, Xu X, Dong J, et al. The psychological impact of the COVID-19 epidemic on college students in China. Psychiatry Res 2020;287:112934. [PubMed] [CrossRef]

9. Liu K. How I faced my coronavirus anxiety. Science 2020;367: 1398. [PubMed] [CrossRef]

10. Stein MB. Editorial: COVID-19 and anxiety and depression in 2020. Depress Anxiety 2020;37:302. [PubMed] [CrossRef]

11. Grigoriadis S, Graves L, Peer M, Mamisashvili L, Tomlinson G, Vigod SN, et al. Maternal anxiety during pregnancy and the association with adverse perinatal outcomes: systematic review and meta-analysis. J Clin Psychiatry 2018;79:17r12011. [PubMed] [CrossRef]

12. Faul F, Erdfelder E, Buchner A, Lang AG. Statistical power analyses using $\mathrm{G}^{*}$ Power 3.1: tests for correlation and regression analyses. Behav Res Methods 2009;41:1149-60. [PubMed] [CrossRef] 
13. Guillén-Riquelme A, Buela-Casal G. Meta-analysis of group comparison and meta-analysis of reliability generalization of the State-Trait Anxiety Inventory Questionnaire (STAI). [Article in Spanish] Rev Esp Salud Publica 2014;88:101-12. [PubMed] [CrossRef]

14. Julian LJ. Measures of anxiety: State-Trait Anxiety Inventory (STAI), Beck Anxiety Inventory (BAI), and Hospital Anxiety and Depression Scale-Anxiety (HADS-A). Arthritis Care Res (Hoboken) 2011;63 Suppl 11:S467-72. [PubMed] [CrossRef]

15. Chua TE, Bautista DC, Tan KH, Yeo G, Chen H. Antenatal anxiety: prevalence and patterns in a routine obstetric population. Ann Acad Med Singapore 2018;47:405-12. [PubMed]

16. Pavlov M, Steiner N, Kessous R, Weintraub AY, Sheiner E. Obstetric and neonatal outcome in patients with anxiety disorders. J Matern Fetal Neonatal Med 2014;27:1339-42. [PubMed] [CrossRef]

17. Davey HL, Tough SC, Adair CE, Benzies KM. Risk factors for sub-clinical and major postpartum depression among a community cohort of Canadian women. Matern Child Health J 2011;15:866-75. [PubMed] [CrossRef]

18. Rose MS, Pana G, Premji S. Prenatal maternal anxiety as a risk factor for preterm birth and the effects of heterogeneity on this relationship: a systematic review and meta-analysis. Biomed Res Int 2016;2016:8312158. [PubMed] [CrossRef]

19. Ding XX, Wu YL, Xu SJ, Zhu RP, Jia XM, Zhang SF, et al. Maternal anxiety during pregnancy and adverse birth outcomes: a systematic review and meta-analysis of prospective cohort studies. J Affect Disord 2014;159:103-10. [PubMed] [CrossRef]

20. Littleton HL, Breitkopf CR, Berenson AB. Correlates of anxiety symptoms during pregnancy and association with perinatal outcomes: a meta-analysis. Am J Obstet Gynecol 2007;196: 424-32. [PubMed] [CrossRef]

21. Kawanishi Y, Hanley SJ, Tabata K, Nakagi Y, Ito T, Yoshioka $\mathrm{E}$, et al. Effects of prenatal yoga: a systematic review of ran- domized controlled trials. [Article in Japanese] Nihon Koshu Eisei Zasshi. 2015;62:221-31. [PubMed] [CrossRef]

22. Yılmaz G, Akça A, Esen O, Salihoğlu Z. Multimedia education on the day of elective cesarean section increases anxiety scores. Perinatal Journal 2019;27:38-42. [CrossRef]

23. De Rosa S, Spaccarotella C, Basso C, Calabrò MP, Curcio A, Filardi PP, et al. Reduction of hospitalizations for myocardial infarction in Italy in the COVID-19 era. Eur Heart J 2020;41: 2083-8. [PubMed] [CrossRef]

24. Huet F, Prieur C, Schurtz G, Gerbaud E, Manzo-Silberman $\mathrm{S}$, Vanzetto G, et al. One train may hide another: acute cardiovascular diseases could be neglected because of the COVID-19 pandemic. Arch Cardiovasc Dis 2020;113:303-7. [PubMed] [CrossRef]

25. Metzler B, Siostrzonek P, Binder RK, Bauer A, Reinstadler SJ. Decline of acute coronary syndrome admissions in Austria since the outbreak of COVID-19: the pandemic response causes cardiac collateral damage. Eur Heart J 2020;41:1852-3. [PubMed] [CrossRef]

26. Garcia S, Albaghdadi MS, Meraj PM, Schmidt C, Garberich $\mathrm{R}$, Jaffer FA, et al. Reduction in ST-segment elevation cardiac catheterization laboratory activations in the United States during COVID-19 pandemic. J Am Coll Cardiol 2020;75:2871-2. [PubMed] [CrossRef]

27. Li S, Wang Y, Xue J, Zhao N, Zhu T. The Impact of COVID19 Epidemic declaration on psychological consequences: a study on active Weibo users. Int J Environ Res Public Health 2020;17:2032. [PubMed] [CrossRef]

28. Durankuş F, Aksu E. Effects of the COVID-19 pandemic on anxiety and depressive symptoms in pregnant women: a preliminary study. J Matern Fetal Neonatal Med 2020:1-7. [PubMed] [CrossRef]

29. Wu Y, Zhang C, Liu H, Duan C, Li C, Fan J, et al. Perinatal depressive and anxiety symptoms of pregnant women along with COVID-19 outbreak in China. Am J Obstet Gynecol 2020:S0002-9378(20)30534-2. [PubMed] [CrossRef] 